\author{
Halina Pelcowa \\ Uniwersytet Marii Curie-Skłodowskiej w Lublinie \\ Instytut Filologii Polskiej \\ Zakład Historii Języka Polskiego i Dialektologii
}

\title{
GRANICE I POGRANICZA DIALEKTOLOGII I ONOMASTYKI
}

Dialektologia i onomastyka to bliskie sobie dziedziny badawcze, które operują podobnym materiałem, ale stosują różne metody opisu. Wspierają się i uzupełniają, ale „nie są tożsame. Inne są źródła, inny sposób ekscerpcji i zbierania materiału, inne metody leksykograficzne, inny cel tych opracowań" - twierdzi Aleksandra Cieślikowa [2003, s. 27]. Odrębność i wspólnota metodologiczna obu dyscyplin opiera się jednak na swoistych mechanizmach interpretacyjnych, przy czym dialektologia:

pomaga onomastom nie tylko w dociekaniach etymologiczno-motywacyjnych, ale też przybliża kontekst kulturowy, obyczajowy środowiska, swoisty ogląd rzeczy i zjawisk, przez co wprowadza w psychologiczno-pragmatyczne przyczyny kreacji przezwisk [...] [z kolei onomastyka - H.P.] może uzupełniać zbiory gwarowe przezwiskami, spetryfikowanymi w nazwiskach i współcześnie żywymi przezwiskami, nazwami terenowymi i powstałymi w środowisku wiejskim z o o n ima mi; apelatywami topograficznymi spetryfikowanymi w nazwach miejscowych, terenowych; uzupełnieniami fonetycznymi i słowotwórczymi: $\mathrm{z}$ dziedziny antroponimii przede wszystkim o formacje - nomina agentis, z toponimii o nomina loci [Cieślikowa, 2003, s. 27].

Problem zależności obu dyscyplin był wielokrotnie przedmiotem rozważań, w których m.in. zwracano uwagę na kwalifikację onomastyczną i/lub dialektologiczną zjawisk językowych [Gala, 1986, s. 25-36; 1979, s. 75-80; Kosyl, 2001a, s. 447-452; 2001b, s. 431-445; Rzetelska-Feleszko, 2001, s. 411-429; Pelcowa, 2007, s. 11-17], metodologię dialektologiczną w zderzeniu z onomastyczną [Gala, 1986, s. 25-36; Gala, Gala-Milczarek, 2006, s. 141-149; Rzetelska-Feleszko, 1986, s. 69-78; Warchoł, 1986, s. 195-210], miejsce zjawisk onomastycznych w słownikach i atlasach gwarowych [Cieślikowa, 2003, s. 21-27; Rzetelska-Feleszko, 2003, s. 29-33; Pelcowa, 2010, s. 313-319] oraz sposób nazywania i mechanizmy onomazjologiczne. 
O wzajemnym stosunku dialektologii i onomastyki pisano już w latach sześćdziesiątych XX wieku [por. Taszycki, 1963, s. 1-19; Zaręba, 1968, s. 7-25], wskazując na fakt zróżnicowanej materii językowej znajdującej się w gestii obu dyscyplin, z dialektologią badającą całość systemu językowego i onomastyką zajmująca się pewną jego częścią, czyli nazwami własnymi. Z upływem lat zakres badań obu dziedzin poszerzył się i zmienił, ale ich wzajemne relacje nie uległy zasadniczej modyfikacji.

Każda dyscyplina badawcza, w miarę rozwoju i zmiany rzeczywistości pozajęzykowej, odchodzi od swoich pierwotnych założeń. Kierowanie się w stronę innych dziedzin i czerpanie z ich doświadczeń staje się wymogiem czasów. Pisał o tym już ponad dwadzieścia lat temu Sławomir Gala [1986, s. 25-36], wskazując jednocześnie, że bez podłoża gwarowego nie można dokonać pełnej i wiarygodnej analizy nazw osobowych i terenowych, a dialektologia i onomastyka mają wiele zbieżnych elementów interpretacyjnych. Nazwy własne to często zakodowane $\mathrm{w}$ gwarze znaczenia, funkcjonujące $\mathrm{w}$ przestrzeni lokalnej z pierwotną funkcją nazywania jako identyfikacji miejsca, osoby, czasu, które poprzez apelatywizację zyskują nowy wymiar funkcjonalny.

Włączenie metod onomastycznych do dialektologii i dialektologicznych do onomastyki pozwala znacznie rozszerzyć pole badawcze, daje możliwości nakreślenia wszechstronnego obrazu danego zjawiska, wyjaśniania jego kontekstów, wskazania różnorodności uwarunkowań kulturowych i obyczajowych. Ale jednocześnie pewne zjawiska wymykają się jednoznacznej klasyfikacji, tworząc obszar pograniczny, z płynnością i elastycznym oscylowaniem między tym, co tradycyjnie należy do onomastyki lub do dialektologii. Jest pewna liczba zjawisk, które mieszczą się w obu dziedzinach badawczych, ale są też takie, które nie należą w pełni ani do onomastyki, ani do dialektologii. W wielu przypadkach granice między dialektologią i onomastyką wyraźnie zacierają się, w innych rozchodzą się, a zjawiska językowe są kwalifikowane i realizowane zgodnie z metodologicznymi zasadami jednej lub drugiej dyscypliny.

Sposób interpretowania zależy od terytorialnych i historycznie oraz kulturowo uwarunkowanych czynników, sprowadzających się do dwóch wykładników geografii lingwistycznej: miejsca i czasu. Oba są ważne dla obu dyscyplin, chociaż niejednakowo zaznaczające się w badaniach. Powstaje obszar pograniczny, rozumiany jako miejsce między tym, co stałe i tym, co nieustannie się zmienia, przekraczając ustalone granice systemowe, historycznojęzykowe i terytorialne. Zjawiska językowe są przy tym wspierane przez sferę przyjęzykową, np. uwarunkowania obyczajowe i sposób zanurzenia w przestrzeni kulturowej, typ i czas 
osadnictwa, organizację przestrzeni, a także współczesne zmiany techniczne, cywilizacyjne.

Dla badań dialektologicznych szczególnie ważne są zasięg i kulturowe odniesienia oraz relacja nazwy i desygnatu, dla onomastycznych - sfera nazywania i kategoryzacji, ale w obu wypadkach musimy uwzględnić jeden i drugi aspekt, gdyż sposób interpretacji świata jest podobny, tylko opisywany z różnych punktów widzenia, a często też różnymi metodami, które coraz częściej są komplementarne względem siebie.

Wzajemne relacje dialektologii i onomastyki to także problem oddziaływania na siebie nomen appellativum i nomen proprium. Wiedza onomastyczna wzbogacona o etymologię i budowę słowotwórczą nazw pozwala wskazać, które wyrazy pospolite w wyniku onimizacji stają się nazwami własnymi, a które takiej funkcji nie przyjmują.

Jednym z założeń dialektologii jest aspekt onomazjologiczny, który także jest przedmiotem prac onomastycznych, szczególnie ważny przy procesach nazywania przestrzeni wiejskiej, będącej poza zasięgiem spisów urzędowych, w tym nazw ogólnych na określenie części lasów, pól, łąk, dróg, np. niwa 'duży obszar pola uprawnego dworskiego'1 lub 'wielka przestrzeń pól, łąk i lasów', gościniec 'droga wiejska', steczka 'wąska dróżka przez pole', a także lasek 'niewielki las', dębniak 'miejsce, gdzie rosną dęby'. W tym wypadku istotnąjest też rola tradycji lokalnej, zaznaczająca się zarówno w badaniach dialektologicznych, jak i onomastycznych, ale ujmująca wiedzę o tego typu obiektach z różnego punktu widzenia. Nazwy wymienionych desygnatów z jednej strony są włączane do opisu przez dialektologów jako słownictwo z zakresu ukształtowania przestrzeni wiejskiej, z drugiej - przez onomastów jako elementy semantycznej identyfikacji. W obu przypadkach wspólne są zarówno mechanizmy nazwotwórcze, jak i postrzeganie tego typu nazw jako lokalnych identyfikatorów tradycji i tożsamości. Zbieżne mechanizmy interpretacyjne pozwalają też na włączenie takich słów w szersze układy motywacyjne - dla dialektologii w ciagi nazw synonimicznych i heteronomicznych oraz uwikłania onomazjologiczne, dla onomastyki - w typ konstrukcji nazewniczej i klasyfikację semantyczną, morfologiczną czy strukturalną.

Nazwy terenowe, w tym określenia pól, łąk, ich części, a także rodzajów gleby lub ogólnego ukształtowania terenu, należą do wspólnej sfery badań dialektologicznych i onomastycznych. Mają one, po pierwsze, charakter nazw pospolitych, gdyż nie wskazują na konkretny desygnat, ale w ogóle na miejsce

1 Przywołane w artykule przykładowe nazwy i ich znaczenia pochodzą z archiwum autorki artykułu. Jest to materiał zebrany od mieszkańców wsi woj. lubelskiego w latach 1990-2014. 
o specyficznym charakterze i typie, np. łąka w określonym miejscu lub pole rozległe, szerokie, dawne, dworskie, zajmujące dużą przestrzeń, ale też piaszczyste, bagniste, błotniste, kamieniste, podmokłe, nieurodzajne, po wyrąbanym lesie, leżące na uboczu, poza wsią, na pustkowiu, położone między lasami. Przytoczone znaczenia nie wskazują na indywidualny charakter danej nazwy, ale uwypuklają ogólną funkcję nazywania określonej grupy desygnatów. Charakteryzują się przy tym przejrzystą motywacją nazwotwórcza, polegającą na wybraniu „z otaczającej rzeczywistości charakterystycznego elementu i na skojarzeniu go z odpowiednim znanym słowem" [Rzetelska-Feleszko, 2001, s. 412], np.:

borowina, rędzina 'ziemia urodzajna'; glina 'gleba ciemnożółta, z dużą ilością gliny'; siwica, bielica 'gleba podmokła'; popielica, piach, piasek 'gleba piaszczysta'; kamienie, kamionka, szczyrk 'gleba kamienista' - jako elementy konfiguracji barwy gleby i jej składników;

hyz i hel 'otwarta przestrzeń pól, pustkowie', pustka 'pole zdziczałe, nieuprawiane przez wiele lat', nawsie 'droga przez dawną zabudowę wsi' - jako położenie obiektu względem innego lub za czymś czy między czymś;

nowina i kopanina 'pole po wykarczowanym lesie', przymiarek 'kawałek pola gorszego dodany po uwłaszczeniu każdemu gospodarzowi', niwa 'pola uprawne dworskie' - jako przykład rozwoju stosunków gospodarczych i zmian własnościowych.

Po drugie - mogą także funkcjonować jako nazwy własne. Funkcję tę przyjmują jednak kontekstowo, gdy są np. nazwami konkretnego pola o wyraźnej lokalizacji przestrzennej.

Wszystkie wymienione właściwości mogą stać się podstawą przekwalifikowania nazwy i jej przesunięcia do klasy nazw własnych, a tym samym być przedmiotem badań dialektologii i onomastyki. Następuje przejście:

z klasy nazw pospolitych do klasy nazw terenowych własnych, wskazujących już np. nie na rodzaj gleby, ale na pole w określonym miejscu i o określonej nazwie, która jest elementem identyfikującym, np. nazwami własnymi zostają określenia: Adamowe pole - według informatora żartobliwe wskazanie na konkretne pole o kamienistym podłożu, a także margiel 'pole o podłożu kamienistym' czy smukowisko 'pole położone na terenie podmokłym' [Pelcowa, 2007, s. 13].

Także: łęg 'pola podmokłe nad rzeką’' Łęg 'nazwa konkretnego obszaru': Łẹgiem to nazywamy tylko ten kawatek pola, co leży przy samyj rzece, to, co daly już tak sie nie nazywa (wypowiedź z archiwum autorki artykułu, pochodząca z okolic Biłgoraja w woj. lubelskim), niwa 'duży obszar pola dworskiego' i Niwa 'część wsi’: Niwa to część wsi, mówi sie o takich ludziach, że mieszkajo na Niwie (wy- 
powiedź z archiwum autorki artykułu, pochodząca z okolic Zamościa w woj. lubelskim).

A zatem nazwa może odsyłać do konkretnego pola, łąki czy części wsi, ale też może być tylko cechą identyfikującą dany obiekt ze względu np. na położenie, rodzaj gleby czy użyteczność dla człowieka. W związku z tym nadanie mu odpowiedniej nazwy podporządkowane jest działaniu zasady podobieństwa wyglądu, właściwości, sposobu działania, np. szczyrk 'szczere pole, pustkowie' 'żwirowata ziemia z piaskiem' i 'konkretne pole o określonych właściwościach gleby'; niwa 'duży obszar pola uprawnego dworskiego' - 'wielka przestrzeń pól, łąk i lasów' - 'nazwa własna pola lub nazwa części wsi'; wydma 'pole piaszczyste' i wydma 'nazwa pola położonego w ściśle określonym miejscu'; bagno 'trzęsawisko, topielisko' - 'gleba podmokła' - 'roślina Ledum palustre L.' i 'nazwa określonego pola położonego na terenie podmokłym'; wygon 'pastwisko gromadzkie' - 'droga, którą pędzi się bydło na pastwisko’ i 'nazwa własna części łąki’ [por. Pelcowa, 2007, s. 12].

Ewa Rzetelska-Feleszko wskazuje na dwa procesy nominacji onomazjologicznej: w wyniku przeniesienia wyrazu pospolitego do klasy nazw własnych oraz $\mathrm{w}$ procesie derywacji słowotwórczej, przy czym „model powstawania derywatów słowotwórczych polega na odtwarzaniu struktury wyrazów pospolitych z tendencją do przekraczania ograniczeń strukturalnych i semantycznych właściwych wyrazom pospolitym" [Rzetelska-Feleszko, 2001, s. 413]. Można tu przywołać cykl nazw terenowych takich na przykład jak: wydmucha 'gleba piaszczysta' (od wydma), popielarnia, popielica, popielucha 'gleba piaszczysta' (od popiołu), zimnica, zimniucha, wyziębisko 'gleba podmokła' (od zimnej gleby, czyli podmokłej), mokliaki, moczara, mokradło, mokroć, mokrota, mokrzysko 'gleba podmokła' (od mokry), smukowisko 'gleba podmokła' (od smuga), parchowacizna 'gleba podmokła' (od parch), jałowizna 'pole nieurodzajne' (od jałowego podłoża), ladaczyzna 'pole nieurodzajne' (od ladacy 'nieposłuszny').

Podobne relacje między nazwą własną a pospolitą zachodzą też przy określeniach maści zwierząt domowych, szczególnie krów i koni, przy których pojawiają się określenia rzeczownikowe lub przymiotnikowe, będące wtórnie nośnikami nazwy własnej, ale pierwotnie wskazujące na ubarwienie sierści zwierzęcia, a więc wyrazy pospolite, funkcjonujące $\mathrm{w}$ celach identyfikacyjnych nie konkretnego desygnatu, ale całej grupy desygnatów o określonej barwie sierści, np. krasa, krasista, krasula, raba 'krowa w łaty biało-czarne'; szpak 'koń o szarej, popielatej barwie'; deresz 'koń lekko brązowy, o sierści białej przemieszanej z brązowymi włoskami'; bułany 'koń o barwie kawy z mlekiem i białej grzywie'; 
kary 'koń zupełnie czarny’; myszek, myszaty 'koń o szarej, popielatej barwie'; siwy, siwek 'koń o białej sierści'.

Należy przy tym pamiętać, że z tego samego tworzywa co wyrazy pospolite, powstają też nazwy własne, a zatem wszystkie wymienione właściwości mogą stać się podstawą przekwalifikowania nazwy i przesunięcia jej z klasy apelatywów do klasy nazw własnych, np. gniady to nie tylko nazwa związana z kolorem sierści, ale też nazwa własna konia o sierści ciemnobrązowej. Poszczególne określenia koloru sierści mogą przekładać się na sposoby nazywania konkretnego desygnatu, stając się podłożem procesów nominacyjnych, w których nazwa pospolita przechodzi do grupy nazw własnych: gniady - od określenia koloru sierści do nazwy własnej konkretnego konia, czyli Gniadego, krasula od 'określenia maści krowy, a więc każda krowa biało-czarna’ (funkcja apelatywna) do nazwy własnej konkretnej krowy.

Rozważając wzajemne relacje obu omawianych dziedzin badawczych, należy też wskazać, że dialektologa interesuje różnorodność synonimiczna i semantyczna z wielością nazw i znaczeń dla danego desygnatu oraz zróżnicowanie i układy geograficzne nazw, onomasta bada sam proces nazywania i jego motywacje przekładające się na odpowiednią klasyfikację nazw i ich jednostkową niepowtarzalność. Poza tradycyjnym zadaniem dialektologii i onomastyki pozostaje sfera kulturowa i obyczajowa, w którą uwikłana jest nazwa i desygnat. Ten element charakterystyczny dla wielu innych dyscyplin, należy zaliczyć do obszaru pogranicza jako sfery wzajemnych kontaktów językowych i kulturowych. Opisywanie znaczeń słów, wydobywanie ich symboliki czy szukanie obok podstawowych komponentów opisujących słowa, także elementów naddanych, wynika ze swoistej interpretacji świata przez ludność wiejską. Onomastyka nazywa to, co nie tylko wiejskie, ale także miejskie, nie tylko to, co gwarowe, ale także ogólnopolskie. Wchodzi na płaszczyznę polszczyzny standardowej, niedostępnej dialektologii, jest zatem mniej uwikłana w obyczajowość i czynniki kulturotwórcze. Odchodzi też od naiwnej interpretacji świata, stanowiącej ważny element badań dialektologicznych, na rzecz zdroworozsądkowego porządkowania przestrzeni.

Onomastyka zajmuje się nie tylko porządkowaniem czy badaniem nazw własnych, ale też ich etymologią, budową słowotwórczą i tymi właściwościami gramatycznymi, które je różnią od nazw pospolitych. Dialektologia z kolei wychodzi od apelatywów. Granica miedzy nazwami własnymi a pospolitymi nie jest ostra, co powoduje, że - jak już wspominaliśmy - spora grupa nazw jest przedmiotem zainteresowania zarówno dialektologów, jak i onomastów. Problem ten dotyka w największym stopniu zoonimów, fitonimów i antroponimów. 
Na pograniczu dialektologii i onomastyki stoją też niejednokrotnie chrematonimy, odnoszące się zwykle:

do całej serii identycznych z założenia przedmiotów (mnogość jednorodna), a jednocześnie do poszczególnych okazów tej serii. Ze względu na ten szczególny zakres użycia nazwy te zbliżają się do wyrazów pospolitych (istnienie wielu desygnatów sprzyja wytworzeniu się sfery pojęciowej) i mogą być traktowane jako kategoria przejści o wa między nazwami własnymi a pospolitymi [Kosyl, 2001a, s. 448].

Podobną klasą nazw, chociaż rozpatrywanych wyłącznie z perspektywy opisu dialektologicznego, są metonimiczne i metaforyczne przeniesienia nazw ludzi, a także ptaków i zwierząt na inne desygnaty o podobnym wyglądzie, funkcji czy zastosowaniu, np. wojtek 'ptak, bocian: Ciconia'; zofija 'ptak, wilga: Oriolus oriolus'; maciek 'pęcherz'; marcin 'kłosy pozostawione na polu przez nieuwagę kosiarza'; jaś, jasiek 'rodzaj fasoli'; dziad 'niska odmiana fasoli niepotrzebująca tyczek, Phaseolus L.' - 'ostatni pokos' - 'kłosy pozostawione na polu przez nieuwagę kosiarza'; mazur 'niska odmiana fasoli niepotrzebująca tyczek, Phaseolus L.'; żyd 'kłosy pozostawione na polu przez nieuwagę kosiarza' - 'ostatni pokos' - 'ominięty przez nieuwagę oracza kawałek pola'; wasylki, sroczka, koguciki, sikorki, koziołki, bocianki, koniki polne 'chwast, ostróżka polna - Delphinium consolida'; janki,janówki, świętojanki, maciejówki 'wczesne ziemniaki'; bartek 'silny wiatr'; babka 'przyrząd, na którym klepie się kosę'; koza, kozioł 'dawna sieczkarnia ręczna na kosę'; krówka 'owad, biedronka - Coccinella septempunctata' - 'nazwa cukierków'; kukułka 'firletka, roślina łąkowa kwitnąca różowo - Lychnis' - 'nazwa cukierków'.

Wspólną domeną onomastów i dialektologów jest antroponimia ludowa, ze szczególnym miejscem przezwisk i przydomków. Są to zjednej strony nieoficjalne określenia apelatywne, istniejące w ludowej tradycji jako formy identyfikujące i jednocześnie wyrażające relacje międzyludzkie, z drugiej jednak, przechodząc od przezwiska do nazwiska, stają się formami sformalizowanymi urzędowo, odpowiadającymi - jak piszą Sławomir Gala i Beata Gala-Milczarek [2006, s. 145] - na pytania: jaki jest?, czyj jest?, do kogo należy?, skąd pochodzi?, co robi?, kim jest? Taki układ przypomina po części, przeniesioną z etnolingwistyki, a stosowaną $\mathrm{w}$ dialektologii, definicję fasetową $\mathrm{z}$ kulturowym aspektem gwar zawartym w sposobie interpretacji słów. Łącznikiem przenoszącym to, co dialektologiczne, i to, co onomastyczne, jest sposób definiowania, włączający informacje historycznojęzykowe i etymologiczne, często także etymologię ludową, np. dialektolog stara się nie tylko wydobyć nazwę desygnatu, ale zrozumieć motywację i zakres jej użycia, kontekst kulturowy, stosunek do innych nazw oraz miejsce nazwy i desygnatu w określonym kręgu kulturowym, np. skrzyp 'chwast 
polny - Equisetum arvensis' to nie tylko chwast, ale chwast, który wydaje dźwięk: skrzypi, a także chrzęści - stąd chrzastka: jak to nadusiut to skrzypiało i to skrzyp mówili, a mówili tyż chrzęść, bo to tak jak sie ruzmino to chrzęściato tak, rośnie wysoko: to tako wysoko trawa jakby, taki kwost, ma łodyżki rozrywające się: tono tak sie rozrywało, na takie kawołki ta łodyżka, a także ma właściwości lecznicze: ale to też dobre na pluca i tod anemi, to mówili, że to dobre, a i ja sama piłam $z$ tego te zioła, żeby krwi nabrać, i dobre tyż na włosy, na pazory, na wzmocnienie takie ogólne. Dodatkowo mamy informację o wiarygodności opowieści i jest prawdziwości: To prawda jest, ja sama to rubiłam, a z niegdysiejszych casów to zustało. Jak kto ni wierzy to możno sprawdzić, bo to rośnie wszędzie, a znowu zrubienie tego lykarstwa to ni żadne mecyje, tu u nas to mieli przepis na to, ja też wiem jak to zrobić (wypowiedź z archiwum autorki artykułu, pochodząca z okolic Kraśnika w woj. lubelskim).

Według Alfreda Zaręby, ważną cechą łączącą dialektologię i onomastykę jest także diachroniczne ujmowanie zjawisk oraz ich geograficzna lokalizacja [Zaręba, 1968, s. 7-25], co sprzyja wzajemnemu przenikaniu metod badawczych i sposobu interpretacji zjawisk językowych. Istotnym narzędziem opisu dialektologicznego jest mapa, interpretująca i segmentująca rzeczywistość wiejską, dającą nie tylko informacje o desygnacie i jego nazwie, ale też informująca o powiązaniu desygnatu z tłem kulturowym, obyczajowym, społecznym. Wypracowana przez dialektologię metoda geografii lingwistycznej jest wykorzystywana w onomastyce, a wiele zjawisk pojawiających się na mapach dialektologicznych ma także wymiar onomastyczny [por. Kowalska, 1975-1979; MAGP, 1957-1970, a także mapy w regionalnych atlasach dialektologicznych]. E. Rzetelska-Feleszko [1986, s. 75-76] zwraca uwagę, że stosowane od lat kartograficzne ujmowanie zjawisk gwarowych przeniknęło też do onomastyki, dzięki czemu w zarysie metodologicznym obu dyscyplin - dialektologii i onomastyki - zwraca się uwagę nie tylko na nakreślenie zasięgów geograficznych, ale też na śledzenie kierunków dokonujących się procesów językowych [por. m.in.: Rospond, 1964; Lubaś, 1971].

Według S. Gali, „Warsztat pracy onomasty uzależniony jest od stanu wiedzy dialektologicznej" [Gala, 1986, s. 31-32], która powinna być w miarę pełna, a zatem rejestrować możliwie pełny zasób wyrazów przedstawiających „obraz słownikowych i słowotwórczych zróżnicowań polskiego terytorium językowego [Dejna, 1974, s. 193], w tym wszystkie wyrazy nacechowane emocjonalnie, o pierwotnej funkcji apelatywnej, stanowiące podstawę do nominacji nazwotwórczych nazwisk ludowych i przezwisk [por. także: Gala, 1979, s. 75-80]. Zaliczymy tu wyrazy o wyraźnej funkcji ekspresywnej i dużym ładunku emocjonalnym, stanowiące określenie cech fizycznych lub psychicznych osoby nazywanej, ale: 
niemające charakteru przezwisk lub przydomków, np. krzykała 'człowiek, który dużo i głośno krzyczy', garbus 'człowiek mający garb', ciemny 'człowiek niewidomy', jąkała 'człowiek, który się jąka', durny i głupek 'człowiek niezbyt mądry', majkut i lewus 'człowiek, który pisze lewą ręką’, chociaż niewykluczone, że szczególnie w małej wspólnocie komunikacyjnej, każde z tych określeń może funkcjonować też w funkcji nazwy własnej [Pelcowa, 2010, s. 314-315].

Nazwy takie w kolejnych etapach kreacji onomastycznej mogą przechodzić do klasy nazw własnych, np. kulawy 'człowiek utykający na jedną nogę’ i przezwisko osoby ze względu na tę cechę fizyczną: kulawy (o Janku) - nazwa własna, szwargotliwa 'kobieta mówiąca niewyraźnie' i przezwisko przypisane konkretnej kobiecie charakteryzującej się taką właściwością, żótty 'człowiek mający rude włosy' i żólty Maniek - przezwisko, suchy 'o człowiek bardzo szczupłym' i sucha Kaśka - przezwisko [Pelcowa, 2010, s. 319]. Ze względu na swoje cechy - nieoficjalność, fakultatywność i wtórność - mają podobne zakresy rozszerzania denotacji jak wiele nazw pospolitych, wskazujących na istotne właściwości nazywanych desygnatów, np. podobieństwo zewnętrzne do czegoś, sposób zachowania, czynność lub jej wytwór, czy też przeniesienie nazwy na tle podobieństwa desygnatów. Według Czesława Kosyla:

Możliwość odtworzenia motywów i sytuacji, jakie towarzyszyły powstaniu przezwiska, daje dogodną sposobność do ustalenia głównych typów kreacji onomastycznej w zakresie antroponimii. Może to rzucić światło także i na genezę wielu nazwisk, głównie odapelatywnych. Ze względu na sposób, w jaki nazwa wiąże się z desygnatem, wyróżnić można dwa typy nominacji: nominację bezpośrednią (wyraz motywujący nazwę użyty jest w swoim podstawowym znaczeniu) i pośrednią (wyraz motywujący nazwę użyty jest metaforycznie lub metonimicznie) [Kosyl, 2001b, s. 443].

Przywołane zabiegi językowe sytuują się na pograniczu onomastyki i dialektologii, stając się tym samym przedmiotem zainteresowań obu dyscyplin naukowych. W onomastyce, jak pisze $\mathrm{S}$. Gala:

uwzględnienie zasobów leksykalnych i struktur słowotwórczych gwarowych pozwoli lepiej niż dotychczas omówić zagadnienie wzajemnego oddziaływania na siebie nomen appellativum i nomen proprium. Dostarczy wielu nowych argumentów wyjaśniających etymologie i postaci słowotwórcze nazw. Wzbogaceni o sumę takich informacji możemy stwierdzić, które wyrazy pospolite w wyniku animizacji stały się nazwami własnymi, jakie typy słowotwórcze apelatywne i kiedy zaczęły funkcjonować jako antroponimiczne oraz jakie struktury produktywne w antroponimii mogły być przejmowane przez leksykę apelatywną [Gala, 1986, s. 34].

Możemy zatem stwierdzić, że wśród dyscyplin oddziałujących na rozwój onomastyki, udział dialektologii jest istotny i znaczący, bowiem:

Zainteresowanie zróżnicowaniem terytorialnym polszczyzny sprawiło, że zwrócono uwagę także na nazewnictwo własne miejscowe i osobowe funkcjonujące w danej gwarze i noszące 
cechy badanej gwary. Ta zbieżność chronologiczna oraz wiele wspólnych właściwości wyrazów pospolitych i nazw własnych sprawiły, że zarówno na etapie gromadzenia materiału, jak i jego opracowania oraz wniosków antroponimia pozostaje w dużym stopniu zależności od dialektologii i posługuje się metodami dialektologicznymi [Gala, 1986, s. 35].

Z jednej strony mamy pogranicze między dialektologią a onomastyką, z drugiej - twórczą rolę sprzężenia obu dyscyplin dla lepszej interpretacji i wyjaśnienia funkcjonowania zjawisk językowych w warunkach pogranicza interpersonalnego, środowiskowo-lokalnego i historyczno-geograficznego, osadzonego w określonych warunkach osadniczych, migracyjnych, historycznych i w określonej przestrzeni horyzontalnej.

\section{BIBLIOGRAFIA}

Cieślikowa Aleksandra, 2003, Leksykografia onomastyczna a leksykografia gwarowa, w: Gwary dziś. 2. Regionalne słowniki i atlasy gwarowe, red. J. Sierociuk, Poznań, s. 21-27.

Dejna Karol, 1974, Słownictwo ludowe z terenów województwa kieleckiego i łódzkiego (AB), „Rozprawy Komisji Językowej ŁTN”, XX, s. 189-277.

Gala Sławomir, 1979, Słowotwórstwo nazwisk i przezwisk ludności byłego powiatu piotrkowskiego, w: Studia językoznawcze. Streszczenie prac doktorskich, t. 4, s. 75-80.

Gala Sławomir, 1986, Antroponimia a dialektologia - zależności metodyczne, „Acta Uniwersitatis Lodziensis. Folia Linguistica”, 12, s. 25-36.

Gala Sławomir, Gala-MilczareK Beata, 2006, Jeszcze w sprawie metodyki badań pogranicza językowego, w: Spotkania polsko-ukraińskie. Język - Kultura -Literatura, red. H. Pelcowa, Chełm, s. 141-149.

Kosyl Czesław, 2001a, Chrematonimy, w: Współczesny język polski, red. J. Bartmiński, Lublin, s. 447-452.

Kosyl Czesław, 2001b, Nazwy osobowe, w: Współczesny język polski, red. J. Bartmiński, Lublin, s. 431-445.

KowalsKa Anna, 1975-1979, Zróżnicowanie słowotwórcze gwar Mazowsza i Podlasia, t. I-II, Wrocław.

Lubaś Władysław, 1971, Słowotwórstwo południowosłowiańskich nazw miejscowych z sufiksami -ci, -ovci, -inci, itp., Katowice.

MAGP - Mały atlas gwar polskich, 1957-1970, opr. przez zespół Pracowni Atlasu i Słownika gwar polskich, red. K. Nitsch (t. I-II), M. Karaś (t. III-XIII), Wrocław. 
Pelcowa Halina, 2007, Nazwy terenowe w interpretacji dialektologicznej, w: Polszczyzna Mazowsza i Podlasia, t. XI. Nazwy terenowe i nazewnictwo miejskie Mazowsza i Podlasia, red. H. Sędziak, M. Dajnowicz, Łomża, s. 11-17.

Pelcowa Halina, 2010, Onomastyka w słowniku gwarowym, w: W świecie nazw. Księga jubileuszowa dedykowana Profesorowi Czesławowi Kosylowi, red. H. Pelcowa, Lublin, s. 313-319.

Rospond Stanisław, 1964, Patronimiczne nazwy miejscowe na Śląsku, Wrocław. RzetelsKa-FeleszKo Ewa, 1986, Metody dialektologiczne w onomastyce, „Acta Universitatis Lodziensis. Folia Linguistica", 12, Łódź, s. 69-78.

Rzetelska-FeleszKo Ewa, 2001, Nazwy geograficzne, w: Współczesny język polski, red. J. Bartmiński, Lublin, s. 411-429.

Rzetelska-Feleszko Ewa, 2003, Co i ile z onomastyki w regionalnym słowniku gwarowym?, w: Gwary dziś. 2. Regionalne słowniki i atlasy gwarowe, red. J. Sierociuk, Poznań, s. 29-33.

TASZYCKI Witold, 1963, Stosunek onomastyki do innych nauk humanistycznych, „Onomastica”, VIII, s. 1-19.

WARChOє Stefan, 1986, Znaczenie dialektologii w badaniach z zakresu zoonimii, „Acta Universitatis Lodziensis. Folia Linguistica”, 12, s. 195-210.

ZARĘBA Alfred, 1968, Dialektologia a onomastyka, „Onomastica”, XIII, s. 7-25. 